\section{Classical One Step Syntheses of Mono- and Di-Nitrate Sugars via Triflates}

Nighat Afza, Abdul Malik, and Wolfgang Voelter*

Abteilung für Physikalische Biochemie, Physiologisch-chemisches Institut der Universität Tübingen,

Hoppe-Seyler-Straße 1, D-7400 Tübingen-1

Z. Naturforsch. 39b, 840-841 (1984); received January 23, 1984

Sugar Nitrates, Triflate Displacement, Tetrabutylammonium Nitrate

A new approach for the synthesis of some sugar nitrates is described. The reaction sequence consists of esterifying partially protected carbohydrates with trifluoromethanesulfonic anhydride and reacting the resulting triflates with tetrabutylammonium nitrate. This procedure is mild, convenient and has the advantage of protecting highly acid-labile groups.

The nitrate esters of carbohydrates, in particular of polysaccharides, have long been of considerable importance as explosives [1]. In recent years, there has been much interest also in the nitrate esters of simpler sugars which have been found to be useful intermediates in synthetic carbohydrate chemistry [2]. The chief chemical use of such nitrates has arisen from oppurtunities to take advantage of their stability, the easy, selective removal of the nitrate groups from certain positions, and their ready and complete denitration by reductive processes. In addition to their synthetic importance, certain sugar nitrates have biologically, significant properties [2].

To data, most of the syntheses of sugar nitrates have relied upon the esterification of free hydroxyl groups with a variety of nitrating reagents [2]. These not only lack selectivity in presence of acid-labile groups but also require close control of time and temperature. Some sugar nitrates have also been synthesized through displacement of halides with silver nitrate [3] but the method has limited applicability due to competing elimination reactions, molecular rearrangements, and inability to effect displacement in certain positions, particularly when the leaving group is attached to a secondary carbon. A reaction which overcomes many to these limiting factors is the $\mathrm{S}_{\mathrm{N}}-2$ displacement of the triflyl group with tetrabutylammonium nitrate. The effectiveness of

Table I. Physical data of sugar nitrates.

\begin{tabular}{|c|c|c|c|c|c|c|}
\hline $\begin{array}{l}\text { Starting } \\
\text { material }\end{array}$ & Conditions & $\begin{array}{l}\text { Time } \\
{[\mathrm{h}]}\end{array}$ & Products & $\begin{array}{l}\text { Yield }^{\mathrm{a}} \\
{[\%]}\end{array}$ & $\begin{array}{l}\text { M. P. } \\
{\left[{ }^{\circ} \mathrm{C}\right]}\end{array}$ & $\begin{array}{l}{[\alpha]_{\mathrm{D}}^{20}\left(\mathrm{CHCl}_{3}\right)} \\
{\left[^{\circ}\right]}\end{array}$ \\
\hline 1 & $\begin{array}{l}\text { Acetone } \\
\text { (reflux) }\end{array}$ & 12 & $\begin{array}{l}\text { Benzyl 2,3-anhydro- } \\
\beta \text {-L-lyxopyranoside } \\
\text { 4-nitrate }\end{array}$ & 90 & 97 & +75.2 \\
\hline 2 & $\begin{array}{l}\text { Acetone } \\
\text { (reflux) }\end{array}$ & 12 & $\begin{array}{l}\text { Benzyl 2,3-anhydro- } \\
\alpha \text {-D-lyxopyranoside } \\
4 \text {-nitrate }\end{array}$ & 97 & $34-35$ & +63.2 \\
\hline 3 & $\begin{array}{l}\text { Acetone } \\
\text { (reflux) }\end{array}$ & 12 & $\begin{array}{l}\text { Benzyl 2,3-anhydro- } \\
\beta \text {-L-ribopyranoside } \\
\text { 4-nitrate }\end{array}$ & 91 & 100 & -16.2 \\
\hline 4 & $\begin{array}{l}\text { Benzene } \\
\text { (reflux) }\end{array}$ & 14 & $\begin{array}{l}\text { 1,2:5,6-Di-O-isopropylidene- } \\
\alpha \text {-D-glucofuranose } \\
3 \text {-nitrate [7] }\end{array}$ & 85 & syrup & -40.2 \\
\hline 5 & $\begin{array}{l}\text { Benzene } \\
\text { (reflux) }\end{array}$ & 4 & $\begin{array}{l}\text { 1,2:3,4-Di-O-isopropylidene- } \\
\alpha \text {-D-galactopyranose } \\
\text { 6-nitrate [7] }\end{array}$ & 94 & 60 & -58.9 \\
\hline 6 & \multicolumn{2}{|c|}{$\operatorname{DMF}\left(40^{\circ} \mathrm{C}\right) 18$} & $\begin{array}{l}\text { Methyl 4,6-O-benzylidene- } \\
\alpha \text {-D-altropyranoside } \\
\text { 2,3-dinitrate [8] }\end{array}$ & 71 & $47-48$ & +68.6 \\
\hline 7 & \multicolumn{2}{|c|}{$\operatorname{DMF}\left(40^{\circ} \mathrm{C}\right) 18$} & $\begin{array}{l}\text { Methyl 4,6-O-benzylidene- } \\
\alpha \text {-D-glucopyranoside } \\
\text { 2,3-dinitrate [9] }\end{array}$ & 77 & $123-124$ & +87.1 \\
\hline 8 & \multicolumn{2}{|c|}{ DMF $\left(40^{\circ} \mathrm{C}\right) 14$} & $\begin{array}{l}\text { Methyl 2,3-dimethyl- } \\
\beta \text {-D-glucopyranoside } \\
\text { 4,6-dinitrate }[10]\end{array}$ & 70 & $98-99$ & -20.2 \\
\hline
\end{tabular}

\footnotetext{
a The isolated yield.
}

* Reprint requests to Prof. Dr. Wolfgang Voelter. 
this reaction can be attributed to a combination of two factors, the unusual ease of displacement of triflyl group and the enhanced nucleophilicity of the nitrate groups at, both, primary and secondary posisalt. This combination permits facile introduction of nitrate groups at, both, primary and secondary positions. The selectivity of the procedure has been demonstrated by the formation of mono- and di-nitrate sugars in the presence of acid-labile protecting groups like oxirane ring, cyclic acetals and alkyl ethers.

As model substances we synthesized benzyl 2,3anhydro-4-triflyl- $\alpha$-D-ribopyranoside (1) [4], benzyl 2,3-anhydro-4-triflyl- $\beta$-L-ribopyranoside (2) [4], benzyl 2,3-anhydro-4-triflyl- $\alpha$-D-lyxopyranoside (3) [4], 1,2:5,6-di-O-isopropylidene-3-triflyl- $\alpha$-D-allofuranose (4) [5], 1,2:3,4-di-O-isopropylidene-6triflyl- $\alpha$-D-galactopyranose (5) [6], methyl 4,6-O- benzylidene-2,3-bistriflyl- $\alpha$-D-glucopyranoside (6), methyl 4,6-O-benzylidene-2,3-bistriflyl- $\alpha$-D-altropyranoside (7), and methyl 2,3-dimethyl-4,6-bistriflyl$\beta$-D-galactopyranoside $(\mathbf{8})$. The triflates $(\mathbf{1 - 8})$ were reacted respectively with tetrabutylammonium nitrate under the conditions described in Table I. The resultant products were isolated by direct crystallization or column chromatography over silica gel, and identified by their elemental analyses as well as spectral data.

In the light of the foregoing account it may be concluded that the displacement of triflyl group by tetrabutylammonium nitrate competes with other available methods in terms of yields of sugar nitrates. The method, however, imparts greater degree of selectivity in presence of acid-sensitive functions, and does not encounter undesirable rearrangement or elimination reactions.
[1] T. L. Davis, Chemistry of Powder and Explosives, Vol. II, J. Wiley, New York 1943.

[2] J. Honeyman and J. W. W. Morgan, Adv. Carboh. Chem. 12, 117 (1957).

[3] R. S. Tipson, Adv. Carboh. Chem. 8, 107 (1953).

[4] R. Kimmich and W. Voelter, Justus Liebigs Ann. Chem. II, 1100 (1980).

[5] L. D. Hall and D. C. Miller, Carboh. Res. 47, 299 (1976).
[6] R. W. Binkley, M. G. Ambrose, and D. G. Hehemann, J. Org. Chem. 45, 4387 (1980).

[7] J. Honeyman and T. C. Stenning, J. Chem. Soc. 1958, 537.

[8] K. S. Ennor, J. Honeyman, C. J. G. Shaw, and T. C. Stenning, J. Chem. Soc. 1958, 2921.

[9] J. Honeyman and J. W. W. Morgan, J. Chem. Soc. 1955, 3660.

[10] J. W. H. Oldham and J. K. Rutherford, J. Am. Chem. Soc. 54, 366 (1932). 